\title{
Remaking Democracy: Ireland as a Role-Model \\ The 2019 Peter Mair Lecture
}

\section{Simon Hix}

Thank you for the invitation to give the Peter Mair lecture this year. This is a great honour and a real delight for me personally. Although I am perhaps best known as a scholar of the EU, I am not going to talk about that or about Brexit! Instead, I am going to talk about my other main research and teaching interest: democracy. More specifically, I am going to talk about Ireland. I am conscious that it is rather audacious to come here, as a Brit, to give a lecture about Irish democracy. But I am a great fan of Irish democracy, as I will explain.

Let me start by telling you about how I know Peter Mair. Peter Mair was my PhD examiner at the European University Institute in 1995. At the EUI, examiners did not just examine the thesis, but students also work closely with them well before getting to the examination. So, I got to know Peter well over several years. I had actually met him before Florence, though, when I was a masters' student at LSE, where Peter had come to give several lectures as a former student of Professor Gordon Smith.

As I said, what I want to talk about today is democracy in Ireland. You might ask, is this talk really about Ireland or about Britain? This is a fair question. When one thinks about some classic works in political science, several famous case studies of countries are not really about those countries. For example, we can go back to Alexis de Tocqueville's (1835) Democracy in America; one of the greatest books about democracy. In many ways, de Tocqueville was actually writing a book about France, as he was trying to persuade the French aristocracy that democracy was a good idea. More recently, when I was in Italy doing 
my PhD, Robert Putnam's (1993) book, Making Democracy Work came out; just as democracy was about to be transformed in Italy, ironically. But, that book was not really about Italy. Putnam was instead trying to make a point about the dangers of declining civil society in America, which he then wrote his next book about (Putnam, 2000). So, in a sense, you could see my talk today as not really about Ireland, but more a reflection of the fact that some aspects of democracy in Britain are broken, and I am looking across the Irish Sea, to our nearest neighbour, for some possible answers to Britain's problems.

So, the key question I am going to try to answer today is this: given that Ireland has experienced all the claimed drivers of populism, such as dramatic economic downturn and mass immigration, why does Ireland seem to be immune from the populist challenges to democracy we have seen in many other countries? And, related to this, can this absence of populism be explained by the particular way democracy works in Ireland?

\section{Demand Side Drivers of Populism: Ireland Should not be Immune}

We can start this story with Peter Mair. Indeed, Peter was a prophet of the populist wave we have experienced in the last decade. Back in 2010-11, when he was writing his book Ruling The Void (Mair, 2013), he had already started to diagnose some of the problems of advanced democracies. We were starting to see some of the seeds of populism at that time, and Peter was worried about where these trends were heading. In the book, Peter documented growing political indifference, declining electoral turnout, declining participation and membership of political parties, declining party cohesion and declining party government, the fragmentation of parties in parliament, political elites increasingly separate from society, and growing opposition towards the EU. Back when he was writing, 
people were sceptical of his predictions. But, in hindsight, it is astonishing how prophetic he was.

Now we can move forward to look at some of the current research on populism. Much of this research has focused on what could be called the "demand side" of the story: the changes in society, the changes in the economy, and the changes in the conditions that have led citizens to change their attitudes towards the democratic system, and to switch their votes to populist parties. These types of arguments fall into two main categories: research that focusses on the economic drivers of populism, and research that focusses on the cultural drivers. The main economic drivers are the "great recession" of 2008-2010, growing income and wealth inequality, and the long-term effects of economic globalisation, in particular its impact on industrial decline (e.g. Dustmann et al., 2017; Colantone and Stanig, 2018, 2019; Piketty, 2019). Then, on the cultural side, the focus has been on shifting cultural values, and in particular public reactions to high levels of immigration and our new multi-ethnic and multi-religious societies (e.g. Eatwell and Goodwin, 2018; Kaufmann, 2018; Norris and Inglehart, 2019). A key claim of this research is that voters have responded negatively to mass immigration and the cultural changes that have resulted from immigration, particular in smaller towns and cities that had not experienced large-scale immigration prior to the 1990s and 2000s. Another aspect of the cultural argument is that there is now a large and growing cultural gap between elites and masses, particularly as a result of an educational divide. So, people who live in cosmopolitan cities, tend to be more highly educated, more supportive of immigration, are more likely to vote for mainstream political parties, whereas lower educated people in smaller towns and cities in industrial decline, are more likely to be opposed to immigration, and vote for populist parties. There is hence also a geographically dimension to both the economic and cultural narratives: of a 
growing divide between globalising cities and declining smaller towns and rural communities.

One example of the research that looks at the economic demand side effects on populism is the work of Italo Colantone and Piero Stanig $(2018,2019)$. Adapting a method used to look at the effects of economic globalization on employment at a local level in the US, Colantone and Stanig measure the "impact shock" from the volume of imports to Europe from China on employment at the regional level: at the Eurostat NUTS level 3,1 which are the geographical units at the level down from the regions in Spain, Italy and Germany, and so on. So, for example, if there has been high imports of cars into the EU, and a region has a high level of employment in the car industry, then that regional has experienced a higher import shock relative to regions that do not have high levels of employment in the car industry. In a series of papers, Colantone and Stanig then find that larger import shocks lead to changes in attitudes towards democracy, support for stronger leaders, and a rightward shift in political preferences, as well as changes in voting behaviour, via higher levels of support for radical-right parties.

Other scholars have looked at the cultural side, and particularly the effect of immigration on support for right wing populist parties. For example, Matt Golder (2003) found that at the aggregate level, in national elections in Europe, the level of immigration in a country magnified the effect of unemployment on support for populist right parties. More recently, and focussing at the local level in France, Diane Bolet (2020) found that the level of migrants in a municipality, interacting with the level of unemployment in the municipality, increased the likelihood that local workers with the same level of skills as the migrants were more likely to vote for the radical right. In other words, a combined effect of migration and

\footnotetext{
${ }^{1}$ Nomenclature of Territorial Units for Statistics.
} 
local labour market competition shaped support for the populist right in this context. In the late 2000s, much of Europe experienced both a high level of migration, of refugees and/or of workers from Central and Eastern Europe, as well as growing labour market competition as a result of the dramatic economic downturn following the global sovereign debt crisis of 2008-10.

[FIGURE 1 ABOUT HERE]

Starting with the economic drivers of populism in Ireland compared to other countries, Figure 1 shows the effect of the great recession on GDP growth rates in several European countries between 2007 and 2014. Greece was, of course, hit hardest, with at least 7 years of negative growth, including a collapse of GDP of 9 per cent in 2011. The evidence here suggests, though, that Ireland was hit second hardest, with a dramatic fall of GDP across the whole period, and in particular a collapse in GDP by more than 4 per cent in two successive year: 2008 and 2009.

\section{[FIGURE 2 ABOUT HERE]}

In the same period, Ireland also experienced one of the fastest rises in economic inequality in Europe. Here, Figure 2 shows the top 10 per cent share of national income between 1990 and 2016. In 1990 Ireland had a relatively equal society, but income inequality has grown very quickly over the past two decades, so much so, that Ireland now has a level of income inequality similar to the UK and other highly unequal societies, and stands in stark contrast to some of the more equal societies in Europe, such as Sweden or Italy.

[FIGURE 3 ABOUT HERE]

Turning to the cultural drivers, Ireland has been transformed by immigration over the past two decades. For example, Figure 3 shows that Ireland has had a comparatively 
high level of annual net immigration, as a percentage of national population, every year since 2006. Overall, the total influx of immigration into Ireland, mainly from Central and Eastern Europe, as a proportion of Irish population is almost unprecedented amongst advanced democracies in the world. Yet, whereas immigration has become a highly salient political issue in many other countries - including France, Germany, Italy, Sweden, and the UK, who are all shown here - immigration has not become politicised in Ireland.

\section{Do Irish Voters have Populist Attitudes?}

So, Ireland has experienced both the main economic and cultural demand-side conditions for growing support for populist parties. Let me now look at whether Irish attitudes have changed in response to these economic and cultural challenges. First of all, what is interesting is that the same socio-demographic characteristics predict populist attitudes in other countries in Europe also predict populist attitudes in Ireland. Table 1 shows the results of a series of regression models of some of the socio-demographic correlates of attitudes towards immigration and strong government, in Ireland compared to 20 other European countries, using data from the 2018 wave (8) of the European Social Survey. The two questions from the survey used here were as follows:

Anti-immigration: "Using this card, would you say that [country]'s cultural life is generally undermined or enriched by people coming to live here from other countries?", where the card shows a 10-point scale from "0, Cultural life undermined" to "10, Cultural life enriched". Answers of 4 or lower on the scale were coded as "antiimmigration". 
Strong government: "Now I will briefly describe some people. Please listen to each description and tell me how much each person is or is not like you. Use this card for your answer. It is important to her/him that the government ensures her/his safety against all threats. She/he wants the state to be strong so it can defend its citizens. Answers: Very much like me, Like me, Somewhat like me, A little like me, Not like me, or Not like me at all". Answers of "Very much like me", "Like me", and "Somewhat like me" were coded as being supportive of strong government.

In terms of the correlates of anti-immigration attitudes and support for strong government, I looked at some of social characteristics that are often associated with support for populist attitudes and populist parties. Specifically, the models include the following characteristics: three particular social classes (working class in manufacturing, working class in the public sector, and small business owners, in comparison to all other social classes); two lower income family income groups (in the bottom 20 per cent, and in the 30-50 percentiles, compared to family incomes in the top half of the distribution); two geographic locations (rural area, and small town, as opposed to a big city or a suburb); men (in comparison to women); and three older age groups ( 45 to 54,55 to 64 , and over 65 , as opposed to people younger than 45). Separate models were estimated for the Irish respondents and the respondents from 20 other countries pooled together - the countries were Austria, Belgium, Estonia, Czechia, Finland, France, Germany, Hungary, Iceland, Italy, Lithuania, Netherlands, Norway, Poland, Portugal, Slovenia, Spain, Sweden, Switzerland, and the United Kingdom. The models were estimated with logistic regression, with country fixed-effects for the models with the 20 countries.

\section{[TABLE 1 ABOUT HERE]}

The results in Table 1 reveal that many of the same socio-demographic factors correlate with anti-immigrant sentiment in Ireland and in other European countries. For 
example, people in lower social classes, from lower family incomes, and older citizens, are more opposed to immigration in both Ireland and in other countries. The picture is less similar between Ireland and other countries in terms of the socio-demographic correlates of attitudes towards strong government. That said, lower income groups, people who live in small towns, and older citizens tend to be more supportive of strong government in Ireland as well as in other countries in Europe.

In short, the economic and cultural changes that have affected Ireland seem to have fed through to similar populist attitudes, as they have done elsewhere in Europe. Nevertheless, these changes in attitudes do not seem to have undermined Irish citizens' support for their national democracy. As Figure 5 shows, Ireland has very high levels of political trust relative to many other countries in Europe. As the figure shows, the per cent of people who tend to trust politicians fell in Ireland as in other countries during the financial crisis in 2008 to 2010, but then picked up pretty quickly after that. Similarly, as Figure 6 shows, Irish people seem very satisfied with their national democracy: up as high as the Swedes.

\section{[FIGURES 5 AND 6 ABOUT HERE]}

We can also look at other measures. For example, turnout in Irish elections has declined slightly over the past few decades: from the mid 70 per cents in the 1980 s to the mid 60 per cents in recent elections. But, again, this decline is moderate compared to many other countries in Europe. For example, turnout in French parliamentary elections has fallen from above 70 per cent in the 1980s to below 50 per cent in the first round of the 2017 election.

Ireland also does not have a radical right populist party, unlike almost every other country in Europe. Ireland has a radical left party, Sinn Féin, which has some populist 
characteristics, and it could be argued that some aspects of populism, such as nationalism and national identity, are channelled into support for Sinn Féin. Also, Sinn Féin attracts some of the same voters as other populist parties in Europe, such as lower income and voters in lower social classes. But, other populist positions, such as opposition to immigration, are absent from Sinn Féin's platform. Hence, whereas Irish negative attitudes towards immigration seem to be driven by similar socio-demographic characteristics as in other countries, these negative attitudes have not fed through into support for a party with an anti-immigrant platform. Also, Sinn Féin tends to attract younger voters rather than older voters. So older voters, from lower income families, who live in rural areas or small towns, and who are opposed to immigration, are unlikely to support Sinn Féin, but have not mobilised around an alternative (right) populist. Finally, most other countries that have leftwing populist parties like Sinn Féin, such as Syriza in Greece and Podemos in Spain, also have radical right populist parties, such as the Independent Greeks in Greece and Vox in Spain. In contrast, while Ireland has a radical left party with some populist characteristics, it does not have a radical right populist party.

\section{The Supply Side: Ireland's Supplemented Representative Democracy}

So far we have established that from the perspective of the "demand side", Ireland should have experienced the same challenges to its democracy as many other countries. Ireland suffered a major economic shock and has had mass immigration, and these economic and cultural shocks seem to have fed through to anti-immigrant attitudes in the same way in Ireland as in other countries. But, the "supply side" of the challenge to democracy in Ireland - the emergence of a powerful right populist party challenging the mainstream parties, and challenging the democratic institutions themselves - seems completely absent. Could this 
be because Ireland's particular design of democracy has enabled parties and politicians to address the challenges raised by the economic shocks and cultural changes, and so head-off any potential support for a radical right populist party?

Irish representative democracy is of course similar to many other countries in Europe. Ireland has a parliamentary system and a proportional electoral system. Ireland is also a republic. But there are several features of Irish democracy that are quite different to most other democracies in Europe. In fact, I would even go as far as to describe Irish democracy as a "supplemented" form of representative democracy: where several features of Irish democracy improve the representativeness and responsiveness of the system compared to more standard models of representative democracy.

First, Ireland is the only country other than Malta that has a single-transferable-vote (STV) electoral system. STV in Ireland has several interesting features when it comes to responding to public demands for change. STV in Ireland is based on medium-sized districts. As I have argued in other work, with John Carey, proportional representation in moderatelysized districts leads to an ideal trade-off between the representativeness of the electoral system and the stability of the government (Carey and Hix, 2011). This effect is illustrated in Figures 7 and 8.

\section{[FIGURES 7 AND 8 ABOUT HERE]}

Figure 7 shows the Gallagher Disproportionality Index for elections to the Irish and British parliaments since 1992 (Gallagher, 1991). As the figure shows, Irish elections have produced a high degree of correlation between the proportion of votes a party receives (here I have only counted first preferences under STV) and the proportional of seats a party wins in the Dáil. In contrast, recent elections in the UK have produced highly disproportional outcomes (except for the 2017 election), with either Labour or the Conservatives, and more 
recently the Scottish National Party, winning disproportionally more seats than votes and the smaller parties, such as the Liberal Democrats, the Greens and the UK Independence Party, disproportionally fewer seats than votes.

Moreover, this high level of representativeness of Irish elections has not produced unstable governments, as Figure 8 shows. Here, I have calculated the number of days each government in Ireland and the UK was in office since 1992. What is striking is that average length of office of governments in Ireland and the UK has been almost identical. The average government duration in the UK - the epitome of stable government - has been 1,047 days, whereas average government duration in Ireland has been 1,028 days. Hence, Ireland is a good example of the Carey-Hix "sweet spot" argument; where low-magnitude proportional representation has produced both highly representative parliaments as well as stable governments.

In addition, STV does something else that produces highly responsive individual politicians, as it empowers voters to make choices both between parties as well as between politicians from the same party. This creates a high level of electoral competition inside parties, and also creates politicians who are locally focussed. You might say that this over focus on local issues has some negative implications, but in times of crisis, this local focus potentially enables Irish politicians to adapt to and represent local concerns very effectively.

Another feature of STV that I find interesting is the role of independent politicians. The ability of locally-focussed independent politicians to be elected no doubt plays a role in mopping up anti-establishment sentiment, which might otherwise be channelled towards a radical right populist party. These independent members of parliament take away the potential room for a radical right populist party to try to coordinate voters across a number of constituencies. 
A second feature of supplemented representative democracy in Ireland is the use of referendums. After our experience of the Brexit referendum in 2016, this is perhaps not a popular thing to say right now amongst most of my academic colleagues. Nevertheless, Ireland seems to have developed a maturity in how it holds and deals with the outcome of referendums. Ireland has had many referendums compared to all other European countries except Switzerland. So, the Irish public is now used to being directly-engaged in making major policy decisions. The Irish public is also used to the fact that when decisions are made in referendums, the public can change its mind and hold a second referendum at some time in the not too distant future. Moreover, in Ireland referendums are systematically linked up to political processes both inside and outside parliament before a referendum takes place. In addition, Ireland has publicly funded groups campaigning on either side of a referendum debate, which takes the referendum debate away from traditional party lines and the traditional divisions of every-day electoral political. This also prevents one or the other side of a campaign being dominated by one particular party or group of leaders. Other countries should learn from these practices.

So, Ireland has found a mature way to use referendums to address major constitutional or political questions that cut across normal party lines and for dealing with issues that have multi-generational consequences, as opposed to issues that are the usual bread-and-butter issues of electoral politics. These practices stand in contrast, for example, to the recent ad hoc referendums in the Netherlands and the United Kingdom (on the EUUkraine Association Agreement in the former case and the UK's membership of the EU In the latter case), where the campaigns in these referendums were captured by one particular party or group of parties, and many voters ended up making choices in the ballot box on 
issues that were not directly related to the subject of the referendums; such as punishing the political and economic establishment.

The Irish experience of referendums also seems rather different to the ballot initiatives in California, where I have lived on several occasions. There, referendums tend to be captured by powerful concentrated interest groups, who are able to trigger a ballot initiative with a certain number of signatures, and are then able to organise grass-roots movements and to dominate the campaigns. Many citizens seem to sign ballot initiatives without knowing the groups behind the initiative. In Ireland, in contrast, referendums that amend the constitution must be approved by both the Dáil and the Seanad, which is a significant constraint on the proliferation of referendums and on the ability of powerful interests to mobilise and capture a particular initiative.

A third aspect of Irish democracy that I find fascinating, and for which there is now growing interest across the democratic world, are the citizens' assemblies. To be more precise, David Farrell and his colleagues characterise this new democratic practice as "deliberative mini-publics" (Farrell et al., 2019a). Deliberative mini-publics have two key features: 1) they are "deliberative", in that participants reach their conclusions after engaging in a careful and open discussion about the issues, on the basis of information they have all received; and 2) it is a "mini-public", in that its members constitute, so far as possible, a representative subset of a local, regional, or national population, and are hence usually chosen through some form of randomised selection process. Together these two features hark back to Athenian or Rousseauian direct democracy - although in a more structured and systematically deliberative way - and hence stand in contrast to "representative" democracy as it has been practiced since the late $18^{\text {th }}$ century. That said, deliberative mini-publics tend to supplements to rather than replacements of 
representative democracy; to find consensus and compromise on issues when standard representative processes have produced gridlock and/or polarisation, or have ignored a salient issue altogether.

Ireland has been at the forefront of using deliberative processes to supplement representative institutions (e.g. Farrell et al., 2019b). The two main examples have been the Constitutional Convention in 2012-14 and the Citizens' Assembly in 2016-18. The Constitutional Convention involved a mini-public of 66 randomly-selected citizens and 34 politicians from the Irish parliament. The Convention made nine recommendations to the Irish parliament, of which three were taken up in referendums: two in May 2015, on legalising same-sex marriage (which passed), and reducing the age of eligibility for the presidency from 35 to 21 (which was rejected); and a third in October 2018, on removing the offence of blasphemy from the Constitution (which passed).

The Citizens' Assembly then followed, and was based on a similar model, although with all 99 members chosen randomly from the public. The Citizens' Assembly was tasked with debating five topics: abortion, fixed-term parliaments, referendums, population ageing, and climate change. The main consequence of the Citizens' Assembly was a referendum in May 2018 on replacing the constitutional prohibition on abortion with a provision allowing the Irish parliament to legislate on the issue; which it duly did, passing an act that allows for abortion up to 12 weeks. The other recommendations of the Citizens' Assembly are still working their way through the Irish parliament, but there is already discussion about extended this method to other issues, such as a deliberative mini-public to decide whether Dublin should have a directly-elected mayor.

Other countries should learn from Ireland's use of these deliberative supplements to representative democacy, particularly in the face of rising populism, where standard 
electoral and representative processes seem incapable of resolving highly divisive and polarising issues. Most obviously from a British perspective I am referring to Brexit. A deliberative mini-public could have been established soon after the referendum vote to leave the EU in June 2016, to debate what form of Brexit the British government should pursue. For example, Alan Renwick at University College London organized a private citizens assembly on Brexit, which resulted in a broadly-supported compromise for a softer form of Brexit: where the UK stays close to EU regulatory standards in return for extensive membership of the EU single market, to minimise the impact of Brexit on the British economy (Renwick et al., 2018). A publicly organized citizens' assembly on Brexit may have cut through the battles inside the House of Commons and allowed for a compromise solution to emerge, as well as more quickly and less divisively than it eventually did.

A fourth feature of Irish democracy I find fascinating is the way the Irish President stands above the political fray, and is widely seen as a "president of all the Irish", including people who identify as Irish beyond the Irish borders. The president is not chosen by political elites, or associated with one particular political party or tribe, and as a result is able to act as a non-partisan figurehead above the body politic: an elected monarch, if you like. This is almost a unique in advanced democracies, where directly-elected presidents are inevitably part of the party-political battle for political offices. I am not sure how Ireland has managed to achieve a different, more benign, outcome, despite having a directly-elected president. This should be the subject for future research, as I suspect this is a model that many other republics would like to follow.

In short, what I have argued is that as a result of the "supplemented" aspects of Irish democracy, Ireland has managed to achieve highly representative institutions, highly accountable politicians, and a deliberative political culture, with citizen's assemblies and 
referendums as mechanisms for cross-cutting or cutting through highly polarising issues where parties are deeply divided. Other countries, in the throes of a populist wave, can only look upon Ireland enviously.

There are other features about Ireland that could explain the lack of right wing populism, and there are lots of other features that correlate with the fact that Ireland has been a democratic success story. Ireland is a relatively small country with a relatively small elite; and has an elite that is highly connected to local places. This might be a result of STV, or it might be the result of other characteristics of Ireland. Also, with a global diaspora and a history of emigration in most families, Ireland has been very open to immigration. However, many other diaspora societies have not had the same openness to immigration, such as Italy, Greece or Poland for example. The particular national identity of Ireland is also potentially unique. Appeals to nationalism in Ireland tend to be about the national liberation experience and the modern revolutionary foundation of the state, which is very different from a national mythology that is based on a more right wing or militaristic conception of victory in war. Also, Irish nationalism has been tempered by the fact that it has tended to be channelled through Sinn Féin or in part also through Fianna Fáil, rather than through more militaristic movements on the right.

\section{Conclusion: Political Science Needs to Understand the Supply Side of Populism}

In sum, Ireland has experienced many of the factors that have undermined representative democracy in many parts of Europe: a major economic downturn as part of the "great recession", growing income inequality, and a huge volume of immigrants as a percentage of its population. Yet Ireland seems largely immune to populist challenges. The Irish public continue to trust their politicians and their democracy, despite the fact that the same socio- 
demographic characteristics seem to predict opposition to immigration in Ireland as in many other countries. Above all, Ireland does not have a radical right populist party, not even a small one, let alone a major one which is a serious contender for government, as is now the case in many countries in Europe.

The answer to this conundrum, I suggest, is the way Irish democracy has been able to adapt and respond to the economic and social challenges faced by the Irish public. In particular, the single-transferable-vote electoral system, in low magnitude multi-member constituencies, referendums, and deliberative mini-publics have created a highly representative polity, highly accountable politics and government, and deliberative democratic processes that have supplemented the existing representative processes.

If we open this discussion up to the broader picture, this argument suggests that we need to start thinking more about the "supply side" of the populism story. Most of the research on populism thus far has focused on the "demand side": how economic and cultural changes have led to a shift from liberal to authoritarian values, which in turn has produced a demand for populist parties and demands for changes to the way society and the economy work. Given the subjects here, it is understandable that much of this research has been done by economists and sociologists. This is where political scientists need to step up, to make the case that there is another side to the story; that there would not be demand for populist parties if there had not been democratic failure. Put another way, the economic and cultural drivers of populism are necessary conditions for populism but are not sufficient. There would not be a collapse in democratic values if democratic institutions worked effectively, and what I have argued today is this is exactly what has happened in Ireland, as a result of the particular way Irish democracy works. 
In short, economic and/or cultural drivers plus representational failure can lead to democratic crisis. But, economic and cultural drivers plus no representational failure does not seem to lead to a democratic crisis, and this is the story of the Ireland. Put this way, many countries could learn a lot from Ireland's model of democracy. 


\section{References}

Bolet, Diane (2020) 'Local Labour Market Competition and Radical Right Voting: Evidence from France', European Journal of Political Research, forthcoming, https://doi.org/10.1111/1475-6765.12378.

Carey, John M. and Simon Hix (2011) 'The Electoral Sweet Spot: Low-Magnitude Proportional Electoral Systems', American Journal of Political Science 55(2) 383-397.

Colantone, Italo and Piero Stanig (2018) 'The Trade Origins of Economic Nationalism: Import Competition and Voting Behavior in Western Europe', American Journal of Political Science 62(4) 936-953.

Colantone, Italo and Piero Stanig (2019) 'The Economic Roots of the Cultural Backlash: Global Competition and Attitudes in Western Europe', working paper.

Dustmann, Christian, Baryy Eichengreen, Sebastian Otten, André Sapir, Guido Tabellini, and Gylfi Zoega (2017) Europe's Trust Deficit: Causes and Remedies, London: Centre for Economic Policy Research.

Eatwell, Roger and Matthew Goodwin (2018) National Populism: The Revolt Against Liberal Democracy, London: Pelican.

Farrell, David M., Nicole Curato, John S. Dryzek, Brigitte Geißel, Kimmo Grönlund, Sofie Marien, Simon Niemeyer, Jean-Benoit Pilet, Alan Renwick, Jonathan Rose, Maija Setälä, and Jane Suiter (2019a) Deliberative Mini-Publics: Core Design Features, Working Paper 2019/5, Centre for Deliberative Democracy and Global Governance, University of Canberra.

Farrell, David M., Jane Suiter, Clodagh Harris, and Kevin Cunningham (2019b) 'The Effects of Mixed Membership in a Deliberative Forum: The Irish Constitutional Convention of 2012-2014', Political Studies, forthcoming, https://doi.org/10.1177/0032321719830936.

Gallagher, Michael (1991) 'Proportionality, Disproportionality and Electoral Systems', Electoral Studies 10(1) 33-51.

Golder, Matt (2003) 'Explaining Variation In The Success Of Extreme Right Parties In Western Europe', Comparative Political Studies 36(4) 432-466.

Kaufmann, Eric (2018) Whiteshift: Populism, Immigration and the Future of White Majorities, New York, NY: Harry N. Abrams.

Mair, Peter (2013) Ruling The Void: The Hollowing of Western Democracy, London: Verso.

Norris, Pippa and Ronald Inglehart (2019) Cultural Backlash: Trump, Brexit, and Authoritarian Populism, Cambridge: Cambridge University Press.

Piketty, Thomas (2019) Capital and Ideology, Cambridge, MA: Harvard University Press. 
Putnam, Robert D. (1993) Making Democracy Work: Civic Traditions in Modern Italy, Princeton, NJ: Princeton University Press.

Putnam, Robert D. (2000) Bowling Alone: The Collapse and Revival of American Community. New York, NY: Simon \& Schuster.

Renwick, Alan, Sarah Allan, Will Jennings, Rebecca McKee, Meg Russell, and Graham Smith (2018) The Report of the Citizens' Assembly on Brexit, London: University College London.

Tocqueville, Alexis de (2000 [1835]) Democracy in America, Chicago, IL: University of Chicago Press. 
Figure 1. Annual Per Cent GDP Growth, 2007-2014

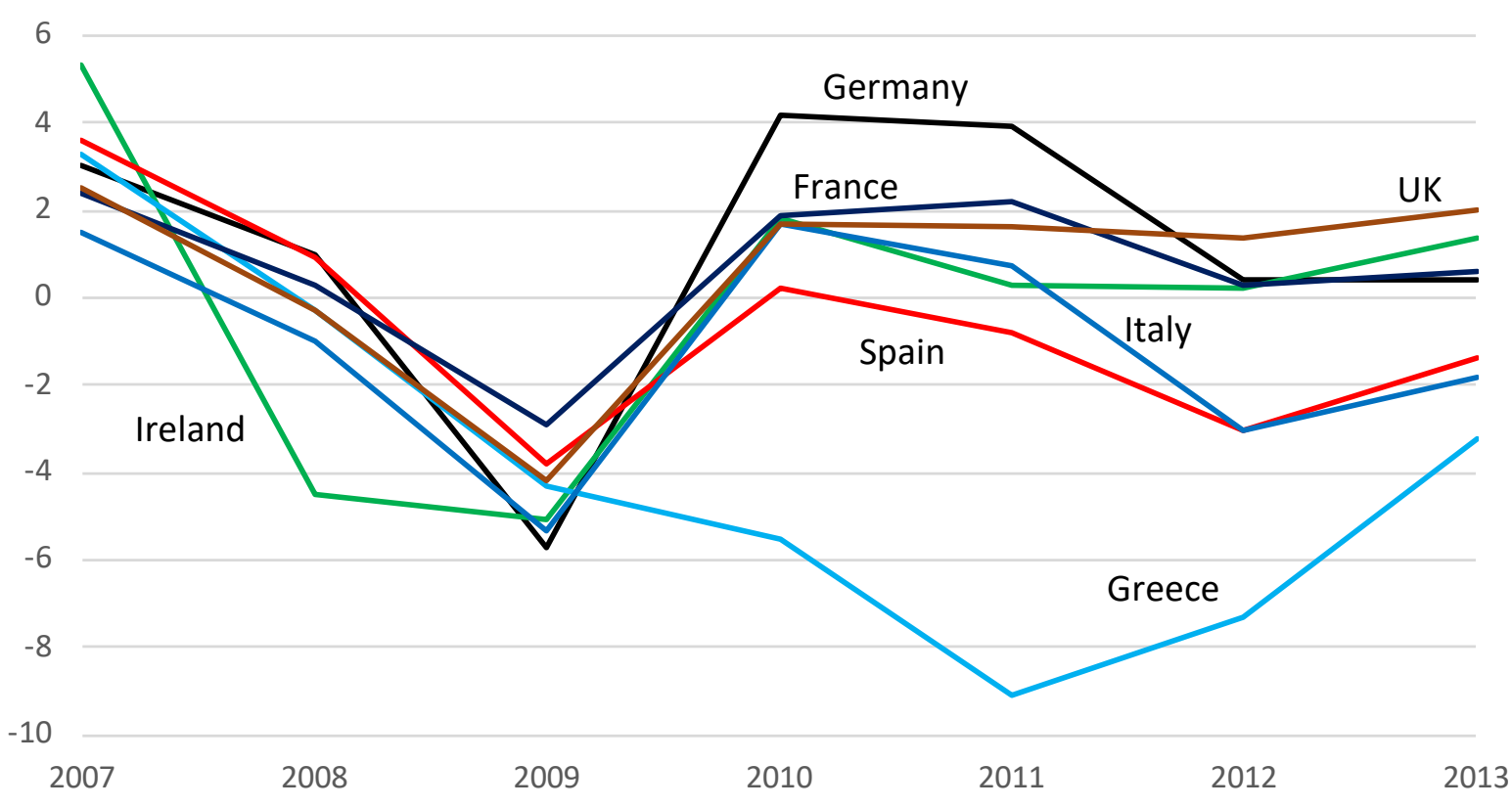

Source: Calculated from Eurostat data.

Figure 2. Top 10 Per Cent Share of National Income

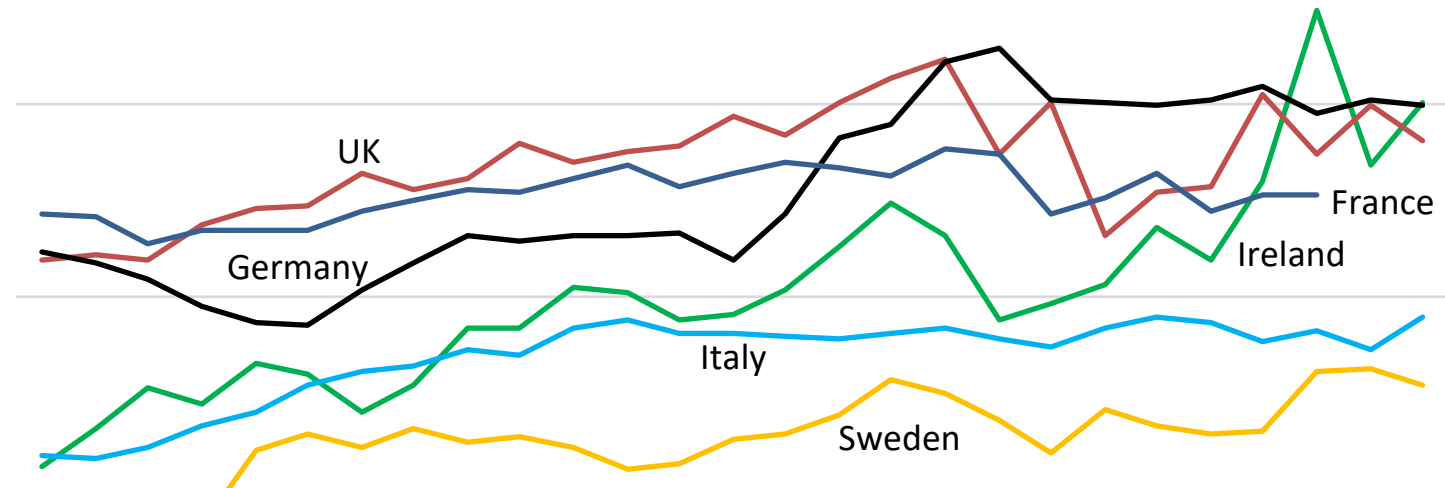
Source: Calculated from World Income Inequality Database. 
Figure 3. Annual Net Immigration as a Per Cent of National Population

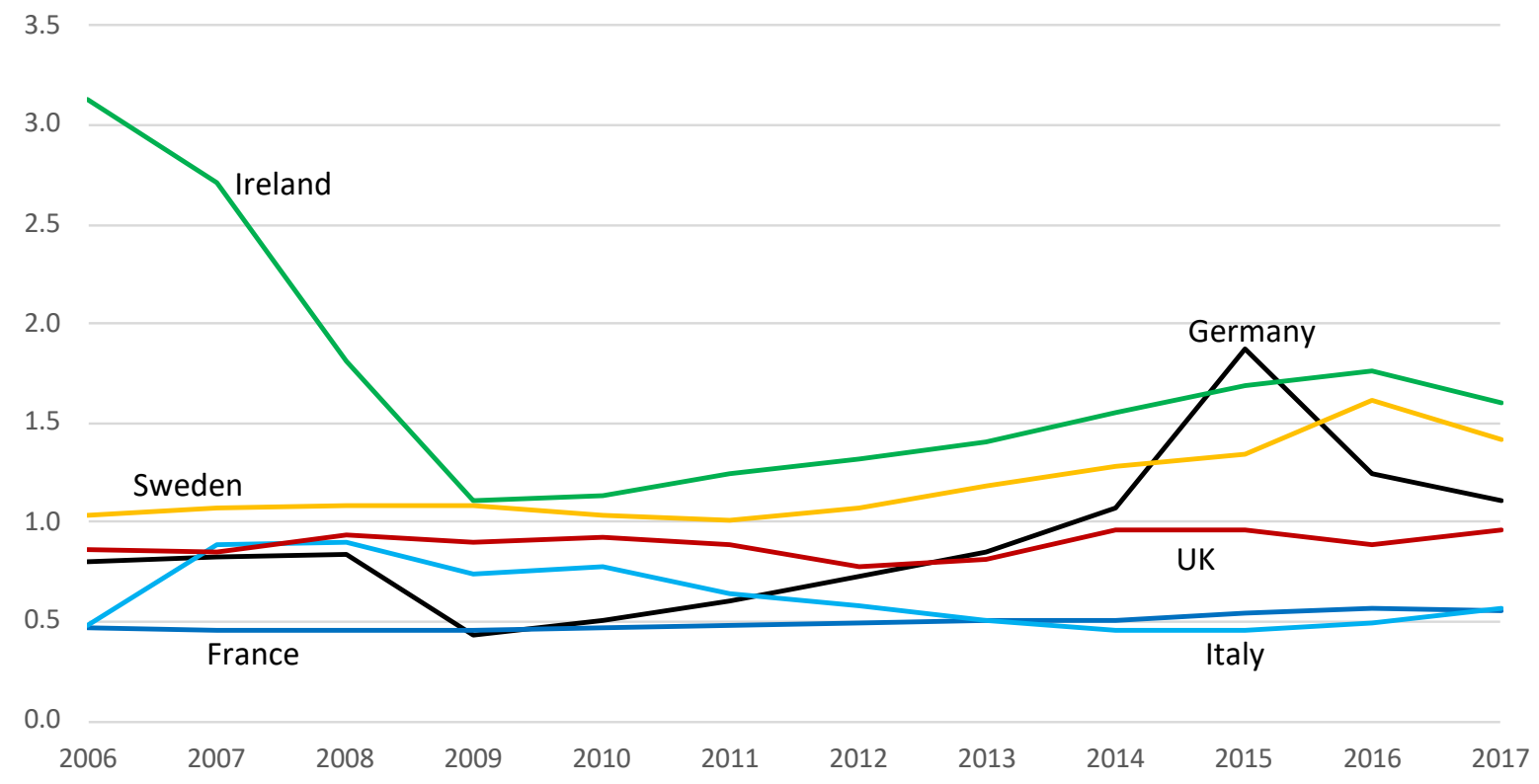

Source: Calculated from Eurostat data. 
Table 1. Correlates of Populist Attitudes in Ireland Compared to Other Countries

\begin{tabular}{|c|c|c|c|c|}
\hline \multirow{3}{*}{$\begin{array}{l}\text { Dependent variable: } \\
\text { Cases: }\end{array}$} & \multicolumn{2}{|c|}{ Anti-immigrant sentiment } & \multicolumn{2}{|c|}{ Support for strong government } \\
\hline & (1) & $(2)$ & (3) & (4) \\
\hline & Ireland & 20 countries & Ireland & 20 countries \\
\hline \multirow{2}{*}{ Working class (manufacturing) } & -0.005 & $0.064 * * *$ & -0.013 & $0.011^{*}$ \\
\hline & $(0.027)$ & $(0.007)$ & $(0.024)$ & $(0.006)$ \\
\hline \multirow[t]{2}{*}{ Working class (public sector) } & $0.141 * * *$ & $0.061 * * *$ & 0.009 & $0.048 * * *$ \\
\hline & $(0.050)$ & $(0.016)$ & $(0.045)$ & $(0.014)$ \\
\hline \multirow[t]{2}{*}{ Small business owner } & $0.135 * *$ & $0.076^{* * *}$ & -0.032 & $0.056 * * *$ \\
\hline & $(0.054)$ & $(0.017)$ & $(0.048)$ & $(0.015)$ \\
\hline \multirow[t]{2}{*}{ Family income in bottom $20 \%$} & $0.071 * * *$ & $0.059 * * *$ & 0.030 & $0.012 * *$ \\
\hline & $(0.021)$ & $(0.007)$ & $(0.019)$ & $(0.006)$ \\
\hline \multirow[t]{2}{*}{ Family income between $30-50 \%$} & $0.042 * *$ & $0.033 * * *$ & $0.036 * *$ & $0.022 * * *$ \\
\hline & (0.019) & $(0.005)$ & $(0.017)$ & $(0.005)$ \\
\hline \multirow[t]{2}{*}{ Live in a rural area } & -0.012 & $0.046 * * *$ & -0.005 & 0.001 \\
\hline & $(0.024)$ & $(0.006)$ & $(0.021)$ & $(0.005)$ \\
\hline \multirow[t]{2}{*}{ Live in a small town } & -0.005 & $0.013 * *$ & $0.027^{*}$ & $0.013 * * *$ \\
\hline & $(0.018)$ & $(0.006)$ & $(0.016)$ & $(0.005)$ \\
\hline \multirow[t]{2}{*}{ Male } & $-0.031^{*}$ & $0.024 * * *$ & $0.027^{*}$ & $-0.013 * * *$ \\
\hline & $(0.016)$ & $(0.005)$ & $(0.015)$ & $(0.004)$ \\
\hline \multirow[t]{2}{*}{ Aged 45 to 54} & 0.026 & $0.029 * * *$ & 0.011 & -0.008 \\
\hline & $(0.023)$ & $(0.007)$ & -0.020 & $(0.006)$ \\
\hline \multirow[t]{2}{*}{ Aged 55 to 64} & $0.068 * * *$ & $0.030 * * *$ & -0.020 & -0.003 \\
\hline & $(0.023)$ & $(0.007)$ & $(0.021)$ & $(0.006)$ \\
\hline \multirow[t]{2}{*}{ Aged over 65} & $0.061^{* * *}$ & $0.051 * * *$ & $0.038 * *$ & 0.008 \\
\hline & $(0.020)$ & $(0.006)$ & $(0.018)$ & $(0.005)$ \\
\hline \multirow[t]{2}{*}{ Constant } & 0.040 & $0.168^{* * *}$ & $0.790 * * *$ & $0.757 * * *$ \\
\hline & $(0.052)$ & $(0.016)$ & $(0.047)$ & $(0.014)$ \\
\hline Observations & 2,757 & 36,643 & 2,757 & 36,643 \\
\hline R-squared & 0.016 & 0.012 & 0.009 & 0.002 \\
\hline Number of countries & 1 & 20 & 1 & 20 \\
\hline
\end{tabular}

Note: Standard errors in parentheses, $* * * p<0.01, * * p<0.05, * p<0.1$. Baseline: other social classes, family income above $50 \%$, live in a big city or a suburb, female, and aged below 45 . Estimation: Logistic regression, with country fixed-effects, in models 2 and 4. Cases in models 2 and 4: Austria, Belgium, Estonia, Czechia, Finland, France, Germany, Hungary, Iceland, Italy, Lithuania, Netherlands, Norway, Poland, Portugal, Slovenia, Spain, Sweden, Switzerland, and the United Kingdom. 
Figure 4. Per cent of People who "Tend to Trust" Politicians

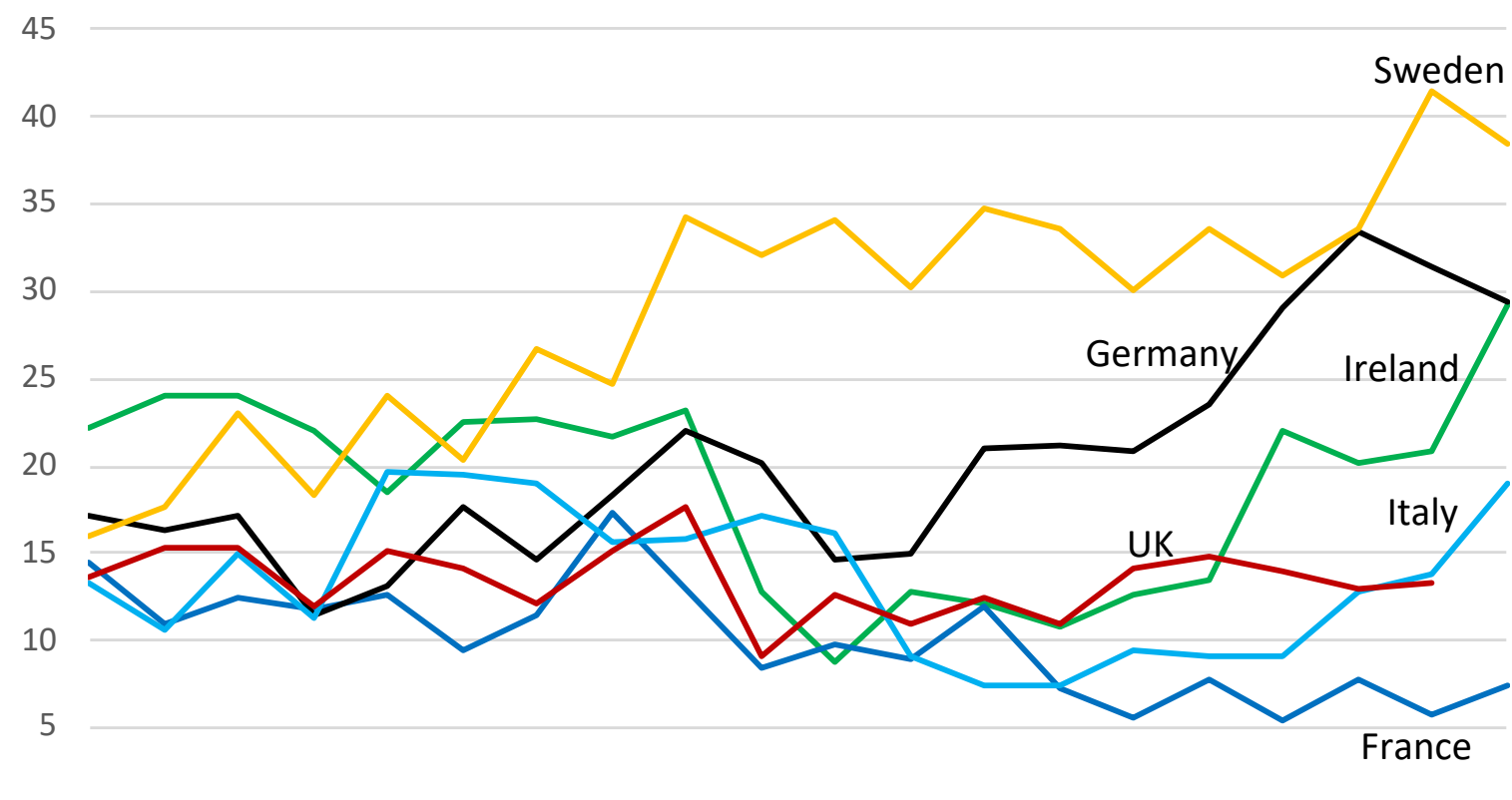

0

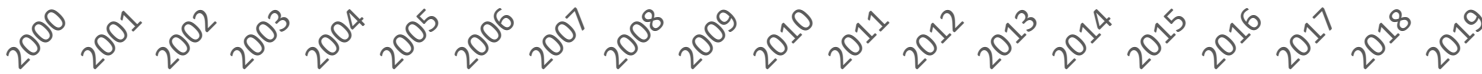

Source: Calculated from Eurobarometer data.

Figure 5. Satisfaction with National Democracy

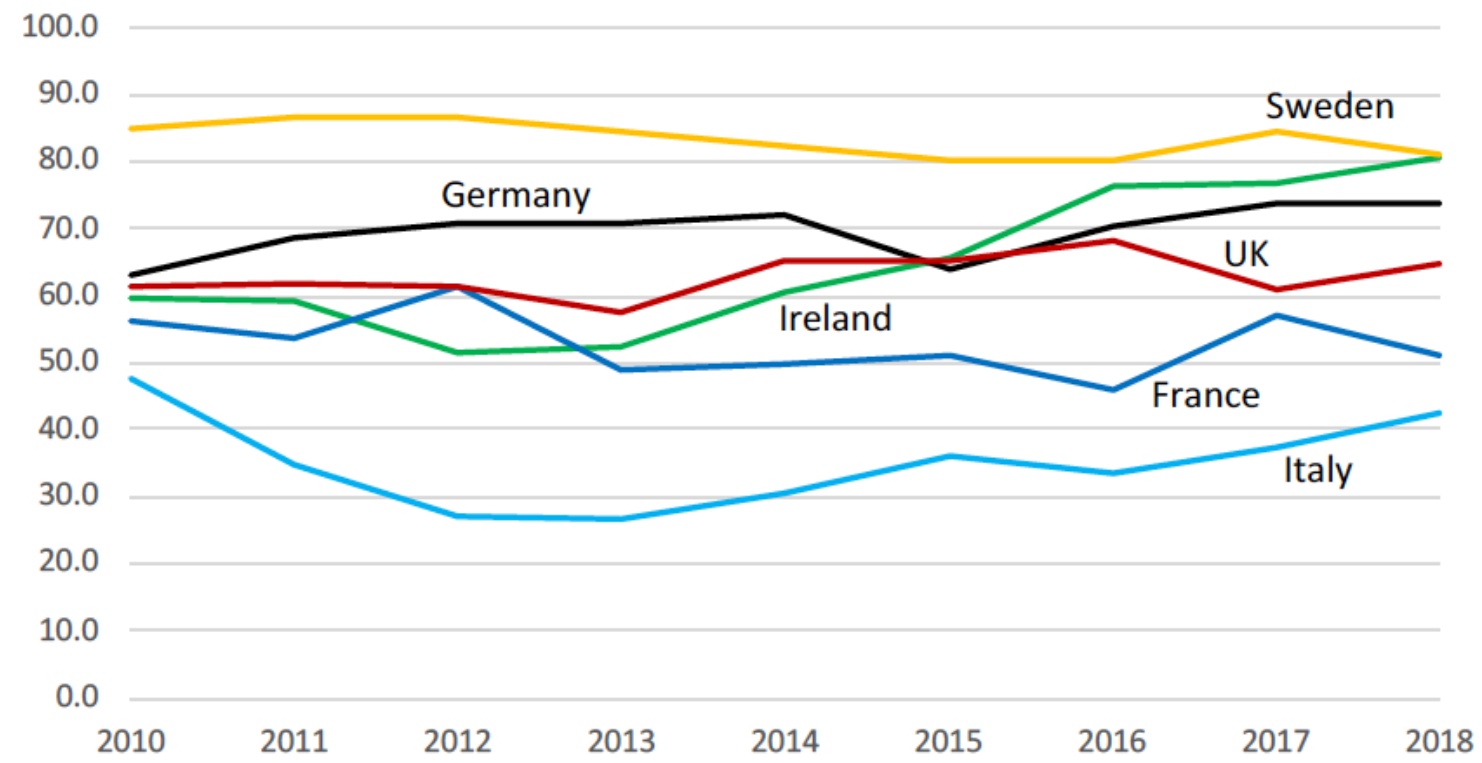

Source: Calculated from Eurobarometer data.

Note: The figure shows the per cent of respondents who are either "very satisfied" or "fairly satisfied". "Don't know" responses are excluded. 
Figure 6. Gallagher Disproportionality Index in Parliamentary Elections in Ireland and the UK

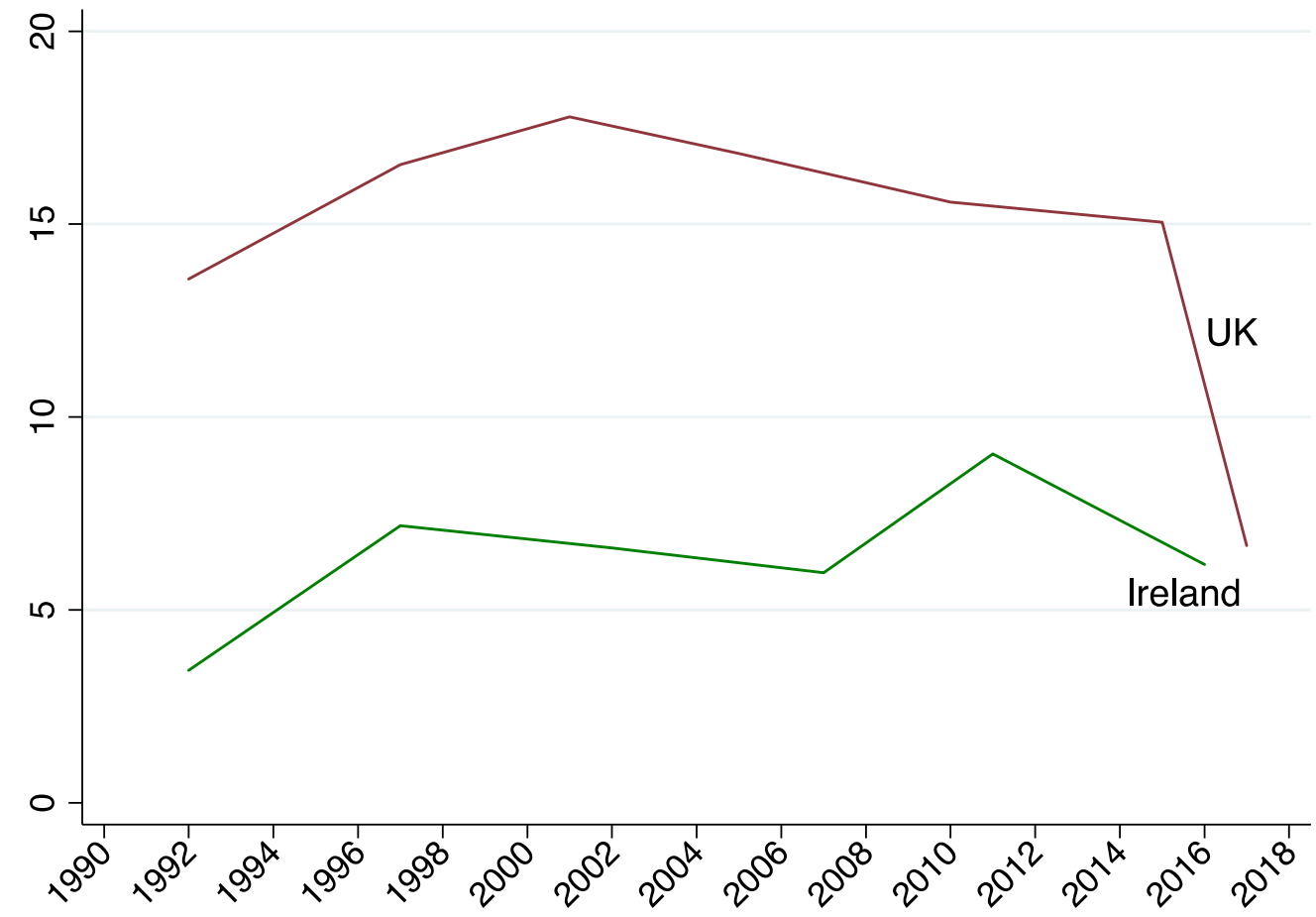

Figure 7. Government Duration in Ireland and the UK since 1992
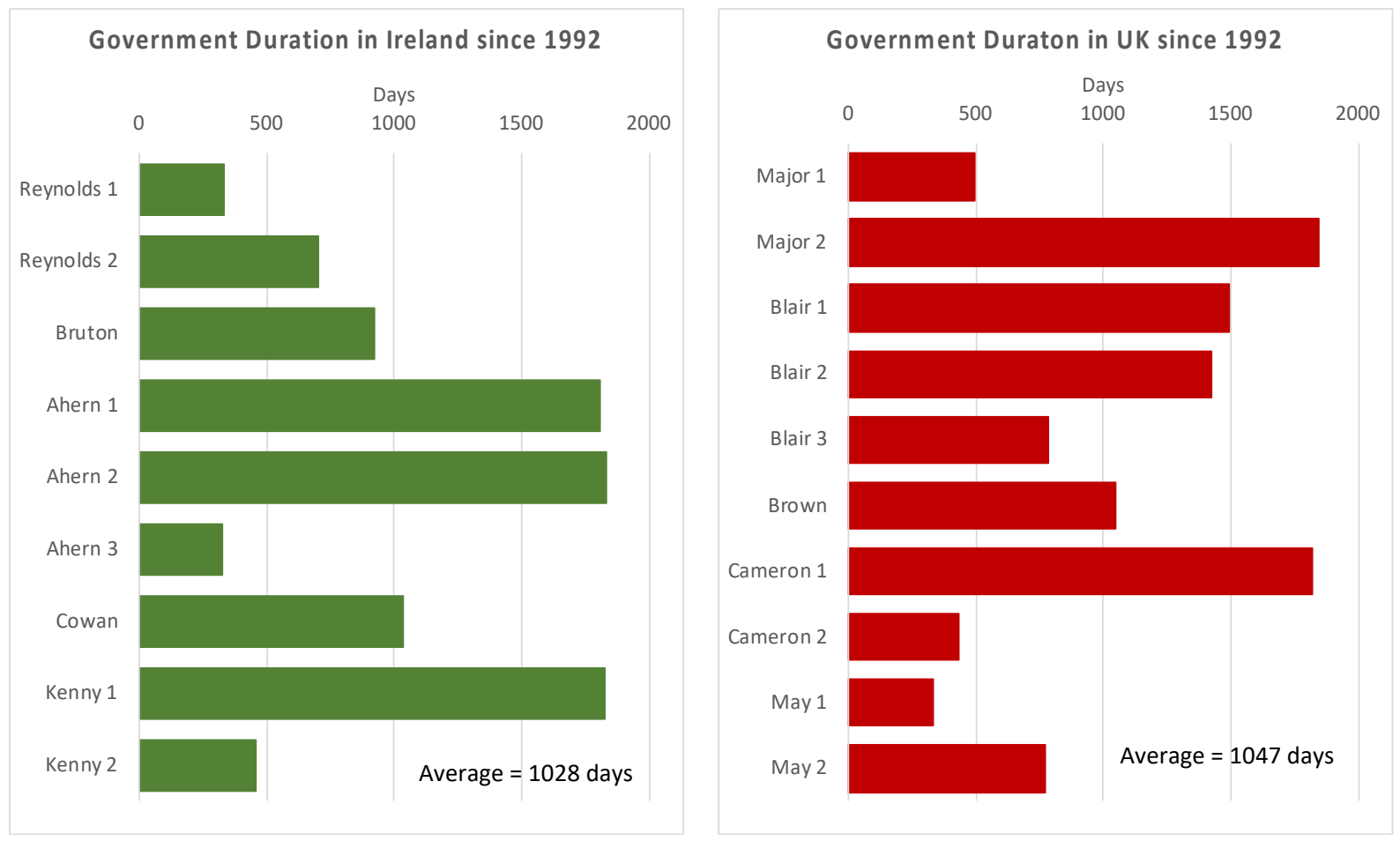